dr inż. Katarzyna Sienkiewicz-Małyjurek ${ }^{1}$

prof. dr hab. Barbara Kożuch ${ }^{2}$

Przyjęty/Accepted/Принята: 28.08.2014;

Zrecenzowany/Reviewed/Рецензирована: 11.02.2015;

Opublikowany/Published/Опубликована: 31.03.2015;

\title{
System zarządzania bezpieczeństwem publicznym w ujęciu teorii złożoności. Opracowanie modelowe
}

\author{
System of Public Safety Management in Context of Complexity System Theory. \\ Development Model
}

\section{Система управления общественной безопасностью в контексте теории сложности. Модель разработки}

\begin{abstract}
A B S T RAKT
Cel: Jako cel niniejszej publikacji przyjęto zdefiniowanie systemu zarządzania bezpieczeństwem publicznym (SZBP) i opracowanie jego modelu w ujęciu teorii złożoności.

Metody: Cel publikacji został osiągnięty na podstawie badań przeprowadzonych w ramach projektu naukowego pt. „Koordynacja, komunikowanie i zaufanie jako czynniki skutecznej współpracy międzyorganizacyjnej w systemie zarządzania bezpieczeństwem publicznym" sfinansowanego ze środków Narodowego Centrum Nauki przyznanych na podstawie decyzji numer DEC-2012/07/D/HS4/00537. Przeprowdzono w tym celu badania desk research literatury polskiej i zagranicznej, a także 15 wywiadów swobodnych z pracownikami policji, straży pożarnej oraz stacji ratownictwa medycznego.

Wyniki: W wyniku przeprowadzonych badań i analiz został rozpoznany i opisany przebieg działań realizowanych w procesie zarządzania bezpieczeństwem publicznym. Zidentyfikowano również grupy podmiotów realizujących działania w tym procesie, a także scharakteryzowano jednostki odpowiedzialne za prowadzenie przedsięwzięć. Na podstawie teorii złożoności został opracowany model SZBP. Został on następnie scharakteryzowany za pomocą cech złożonych systemów adaptacyjnych (CAS). Wnioski: W ramach zrealizowanych badań zidentyfikowano obszar badawczy współczesnego zarządzania bezpieczeństwem publicznym. Zdefiniowano również SZBP jako dynamiczny układ nieskończonej liczby jednostek, którego celem jest zapewnienie bezpiecznych warunków funkcjonowania wszystkim podmiotom na danym obszarze administracyjnym przy wykorzystaniu posiadanych zasobów i w ramach obowiązujących reguł formalnych i nieformalnych relacji, charakteryzujący się niepowtarzalnością i zmiennością działań oraz ciągłym dostosowywaniem się do aktualnych warunków i pojawiających się potrzeb. W systemie tym kompetencje poszczególnych jednostek uzupełniają się, a podejmowanie przedsięwzięć wynika z uwarunkowań prawno-organizacyjnych, sytuacyjnych, a także codziennej praktyki służącej wzmocnieniu formalnych i nieformalnych relacji i zachowań poszczególnych jednostek. Dalsze pogłębione badania wymagają zidentyfikowania i poddania analizie czynników wpływających na skuteczność przedsięwzięć realizowanych w SZBP.
\end{abstract}

Słowa kluczowe: zarządzanie publiczne, bezpieczeństwo publiczne, system zarządzania bezpieczeństwem publicznym SZBP, teoria złożoności, złożony system adaptacyjny (Complex Adaptive System - CAS)

Typ artykułu: oryginalny artykuł naukowy

Politechnika Śląska, Wydział Organizacji i Zarządzania, Instytut Zarządzania i Administracji, Zabrze / Silesian University of Technology, Faculty of Organization and Management, Institute of Management and Administration, Poland; wkład merytoryczny/percentage contribution - 60\%;

2 Uniwersytet Jagielloński, Wydział Zarządzania i Komunikacji Społecznej, Instytut Spraw Publicznych, Kraków / Jagiellonian University, Institute of Public Affairs; e-mail: barbara.kozuch@uj.edu.pl; wkład merytoryczny/percentage contribution - 40\%; 


\section{A BSTRACT}

Aim: The purpose of this publication is to define the system of public safety management (PSM) and to create a model in accordance with complexity theory.

Methods: Purpose of the publication was achieved on the basis of research carried out under the project titled "Coordination, communication and trust as factors driving effective inter-organizational collaboration in the system of public safety management". This project was financed by the National Science Centre based on decision reference no. DEC-2012/07/D / HS4/00537. To achieve the aim a desk top exercise was performed, analysing Polish and overseas literature. Additionally, 15 unstructured interviews were conducted with members of the police service, fire service and emergency medical rescue staff. Results: As a result of research and analysis, the public safety management process was established. Entities participating in this process were identified as well as the formations responsible for performing tasks were typyfied. A model of the public safety management system was created based on the complex system theory approach and further enhanced by the features of a complex adaptive systems (CAS).

Conclusions: The performed analysis has revealed a research area covering contemporary public safety management. Additionally, PSM was defined as a dynamic structure of an infinite number of entities whose aim is to ensure the safety of all participants in a given administrative area, using existing resources within established formal rules and informal relationships. This system is characterized by a unique variety of activities and continuous adjustments to a current environment and emerging needs. Under PSM individual competencies of participating establishments complement each other. Operations are undertaken on the basis of legal, organizational and situational circumstances as well as daily practices, which strengthen formal and informal relationships and organisational behaviours of individual entities. Further studies need to identify and analyze the factors, which influence the effectiveness of operations implemented by PSM system.

Keywords: public safety management (PSM), public safety, PSM system, Complexity System Theory, Complex Adaptive System (CAS)

Type of article: original scientific article

\section{АННО ТАЦИЯ}

Цель: Целью данной публикации является определение, чем является система управления общественной безопасностью и разработка её модели в контексте теории сложности.

Методы: Цель публикации была достигнута с помощью исследований, проведённых в рамках научного проекта под названием „Координация, общение и доверие в качестве факторов, обусловливающих эффективное межорганизационное сотрудничество в системе управления общественной безопасностью”, финансируемого Национальным Центром Науки, представленных на основе решения номер DEC-2012/07/D/HS4/0053. Проведённые исследования включали в себя так называемые исследования desk research (кабинетные исследования) польской и зарубежной литературы, а также 15 свободных (нестандартизированных) интервью с сотрудниками полиции, пожарной службы, а также сотрудниками подразделений скорой помощи.

Результаты: В результате проведённых исследований и анализов был выявлен и описан ход действий, реализуемых в процессе управления общественной безопасностью. Были также определены группы субъектов, осуществляющих деятельность в этом процессе, а также охарактеризованы органы, ответственные за реализацию проектов. На основании теории сложности была разработана модель Системы управления общественной безопасностью, которая позже была охарактеризована при помощи признаков комплексных адаптивных систем (CAS).

Выводы: В рамках реализуемых исследований была определена сфера исследований современного управления общественной безопасностью. Была также определена Система управления общественной безопасностью, как динамическая система бесконечного числа единиц, целью которой является обеспечение безопасных условий функционирования всех субъектов на данной административной территории, при использовании имеющихся средств и в рамках обязующих формальных правил и неформальных отношений. Данная система характеризуется уникальностью и изменчивостью действий, а также непрерывной адаптацией к актуальным условиям и возникающим потребностям. В этой системе компетенции отдельных единиц дополняют друг друга, а реализация действий осуществляется в связи с правовыми, организационными и ситуационными условиями, а также в связи с повседневной практикой, направленной на укрепление формальных и неформальных отношений и поведений отдельных единиц. Дальнейшие расширенные исследования требуют идентификации и анализа факторов, влияющих на эффективность действий реализуемых в Системе управления общественной безопасностью.

Ключевые слова: общественное управление, общественная безопасность, система управления общественной безопасностью, теория сложности, комплексная адаптивная система (Complex Adaptive System - CAS)

Вид статьи: оригинальная научная статья 


\section{Wstęp}

W Polsce bezpieczeństwo publiczne jest rodzajem bezpieczeństwa, do którego przywiązuje się największą uwagę, co potwierdzają zapisy w aktach prawnych [1, s. 89]. Tradycyjne podejście do problematyki bezpieczeństwa publicznego koncentruje się na osiąganiu jego pożądanego stanu jedynie poprzez formułowanie odpowiedniej polityki publicznej. Wziąwszy jednak pod uwagę liczbę podmiotów zaangażowanych w realizację działań oraz dynamikę i złożoność uwarunkowań towarzyszących współczesnym zagrożeniom, konieczne jest dokładniejsze rozważenie zagadnienia zarządzania. Istnieje zatem potrzeba intensyfikacji badań w obszarze zarządzania bezpieczeństwem publicznym. Przydatna w tym celu może być teoria złożoności, która pozwala na systemową interpretację bezpieczeństwa [2, s. 159] oraz koncepcja M. Gell-Manna organizacji jako złożonego systemu adaptacyjnego, w której niezależnie od tego, czy przedmiotem analizy jest państwo, czy przedsiębiorstwo głównie podkreśla się ich zdolność do adaptacji [3], [4]. Z tej przyczyny za cel niniejszej publikacji przyjęto zdefiniowanie SZBP i opracowanie jego modelu w ujęciu teorii złożoności.

\section{Metodyka badań}

Wyniki badań przedstawionych w niniejszym artykule zostały przeprowadzone $\mathrm{w}$ ramach projektu naukowego pt. „Koordynacja, komunikowanie i zaufanie jako czynniki skutecznej współpracy międzyorganizacyjnej w systemie zarządzania bezpieczeństwem publicznym" sfinansowanego ze środków Narodowego Centrum Nauki przyznanych na podstawie decyzji numer DEC-2012/07/D/HS4/00537. Obejmowały one badania desk research literatury polskiej i zagranicznej przy wykorzystaniu takich baz danych jak: Scopus, ISI Web of Knowledge i Publish or Perish. Badania te zostały uzupełnione $\mathrm{w}$ wyniku wywiadów swobodnych z 15 pracownikami średniego i niższego szczebla zatrudnionymi w jednostkach policji, straży pożarnej oraz stacjach ratownictwa medycznego.

W artykule przedstawiono analizę wyników badań dotyczących specyfikacji SZBP w ujęciu teorii złożoności. W tym celu niezbędne było przedstawienie najważniejszych elementów teorii złożoności, istoty zarządzania bezpieczeństwem publicznym i odpowiedzialności w tym zakresie. Na tle podstawowych cech złożonych systemów adaptacyjnych (CAS) zanalizowano uwarunkowania realizacji działań w bezpieczeństwie publicznym i zdefiniowano SZBP. W rezultacie został opracowany graficzny model SZBP w ujęciu teorii złożoności.

\section{Teoria złożoności w naukach o zarządzaniu}

Teoria złożoności (complexity theory) stanowi interpretacyjny paradygmat wyjaśniający określone zachowania systemów i ich części składowych. Została ona opracowana na podstawie obserwacji prowadzonych w biologii, a umocniła swoje istnienie w wyniku ciągłego wzrostu niepewności i zmienności środowiska [5], [6]. Stanowi, że właściwości współczesnego świata są rezultatem interakcji zachodzących pomiędzy wszystkimi jego elementami - społecznościami, środowiskiem, ekonomią i techniką. Wszystkie elementy wpływają na formę tej całości, która w każdym momencie charakteryzuje się innymi cechami, jest w stanie ciągłych zmian i zaburzeń, które odgrywają kluczową rolę w tworzeniu nowych wyższych form porządku [7, s. 16]. W naukach o zarządzaniu teoria złożoności została zaadaptowana w latach 90 . na potrzeby badania zachowań organizacji i jej jednostek [8, s. 855], [9, s. 68]. Doprowadziło to do koncentrowania się na środowisku funkcjonowania organizacji, którego głównymi cechami są nieprzewidywalność i zmiana oraz ujmowania organizacji jako nieliniowego układu dynamicznego.

Teoria złożoności doprowadza do zrozumienia, jak systemy mogą spontanicznie ewoluować w kierunku bardziej zorganizowanych i zaawansowanych form. Powszechnie uważa się, że maksymalna kreatywność i innowacyjność są możliwe do osiągnięcia „na krawędzi chaosu", gdy zarówno porządek, jak i chaos istnieją równocześnie [9], [10]. Teoria złożoności poszukuje wspólnych cech systemów złożonych, w których wiele elementów, podsysytemów i czynników współdziała w gęstej sieci powiązań $[11$, s. 56]. Systemy takie mogą być zrozumiałe jedynie w ujęciu całościowym, ponieważ relacje zachodzące pomiędzy ich elementami mają charakter nieliniowy i niezdeterminowany przyczynowo [12]. Uwzględniając zarówno ich strukturę, jak i powiązania $\mathrm{z}$ otoczeniem, $\mathrm{w}$ literaturze przedmiotu nazywane są one złożonymi systemami adaptacyjnymi (Complex Adaptive System - CAS). Jednakże nie każdy złożony system jest adaptcyjny, jak również nie zawsze adaptacja systemu zwiększa szanse na jego przetrwanie. O CAS mówi się w przypadku, gdy adaptacyjność wpływa na elastyczność systemu i poprawia jego skuteczność funkcjonowania [13].

CAS stanowią otwarte, nieliniowe i ewolucyjne układy dynamiczne, które tworzą się w wyniku interakcji zachodzących pomiędzy jego elementami [9, s. 68], [14]. Elementy CAS funkcjonują według własnych indywidualnych reguł, a ich rozwój przebiega nierównomiernie. Zachowania poszczególnych elementów systemu mogą być źródłem konfliktów i konkurencji, które w rezultacie doprowadzają do wzajemnego 
dostosowywania się tych elementów [8, s. 855; 15, s. 485]. Pojedyncze elementy w ramach bezpośrednich i intensywnych interakcji mogą grupować się tworząc nowy, większy organizm. Struktury takie mogą mieć charakter stały bądź tymczasowy. Współdziałanie, na podstawie procesu samoorganizacji, może nieświadomie stworzyć nowe rozwiązanie, nową formę działania.

Właściwości CAS mają charakter wielokierunkowy i sieciowy, a ich zachowanie wynika z oddziaływania wielu czynników i reguł. Podstawowe charakterystyki złożonych CAS obejmują [16, s. 18]: dużą liczbę elementów, zmienność, samoorganizację, różnorodność, dynamizm i żywotność, zdolności adaptacyjne, interakcje, brak liniowości i selekcję. Obejmują również efekty sprzężenia zwrotnego, a w tym kreatywność, adaptację i uczenie się. Wziąwszy pod uwagę powyższe czynniki, można stwierdzić, że CAS są ściśle związane z ich środowiskiem, wrażliwe na wszelkie zmiany w nim zachodzące i ewoluują wraz z nim. Ich podstawowe charakterystyki sprawiają, że stanowią odpowiedni fundament do analizy uwarunkowań zarządzania bezpieczeństwem publicznym. Przy analizie organizacji publicznych $\mathrm{w}$ perspektywie CAS należy podkreślić, iż dla tego typu organizacji szczególnego znaczenia nabierają skutki funkcjonowania, czyli zmiany, jakie organizacja oraz jej produkty powodują w otoczeniu. Najistotniejsze jest więc, na ile organizacja publiczna zachowuje zdolność satysfakcjonowania odbiorców usług publicznych, a w tym bezpieczeństwa publicznego [13, s. 49].

\section{Bezpieczeństwo publiczne pochodną realizowanej polityki państwa}

Bezpieczeństwo publiczne uważane jest za podstawę zasobnego i dobrze funkcjonującego społeczeństwa [17, s. 234], gdyż jest pochodną realizowanej polityki państwa. Jego ważną częścią składową jest podsystem bezpieczeństwa publicznego, którego szeroki zakres podmiotowy dotyczy zarówno organizacji państwowej, wspólnot terytorialnych, jak i pojedynczych osób na danym obszarze administracyjnym, a jego celem jest ograniczanie zagrożeń, zapewnienie niezakłóconego funkcjonowania, a także ochrona życia, zdrowia i mienia wszystkim podmiotom tego podsystemu [18]. Podsystem ten odnosi się do funkcjonowania jednostek, instytucji, organizacji, grup społecznych i poszczególnych obywateli. Określa uwarunkowania istniejące $\mathrm{w}$ danym miejscu i czasie, w których nie występują zagrożenia osób, środowiska i mienia [19].

W literaturze przedmiotu wyróżnić można szerokie i wąskie podejście do problematyki bezpieczeństwa publicznego [20], [21]. W szerszym znaczeniu utożsamiane jest $\mathrm{z}$ bezpieczeństwem narodowym i obejmuje ochronę przed wszelkimi rodzajami zagrożeń. Z kolei węższe ujęcie dotyczy zasad życia społecznego, które zapewniają ochronę przed zagrożeniami o społecznymi i o charakterze naturalnym. Generalnie bezpieczeństwo publiczne definiowane jest jako „taki stan wewnątrz państwa, który umożliwia bez narażenia na szkody (wywołane zarówno zachowaniem ludzi, jak i działaniem sił natury, techniki itp.) normalne funkcjonowanie organizacji państwowej i realizacje jej interesów, zachowanie życia, zdrowia i mienia jednostek żyjących w tej organizacji (nie tylko obywateli) oraz korzystanie przez te jednostki z praw i swobód zagwarantowanych konstytucją i innymi przepisami prawa" [22, s. 129-130]. Uznawane jest w kategoriach funkcji rządu i obowiązków różnych jednostek, które tworzą charakterystyczny system administracyjny ukierunkowany na zapobieganie i zwalczanie zagrożeń, katastrof i klęsk żywiołowych [23, s. 99]. Do podstawowych rodzajów bezpieczeństwa publicznego należą [24, s. 37]:

- zabezpieczenie przez zamachami na życie, zdrowie i mienie,

- bezpieczeństwo w transporcie i komunikacji,

- bezpieczeństwo sanitarno-epidemiologiczne,

- bezpieczeństwo pożarowe,

- bezpieczeństwo prawne,

- bezpieczeństwo informacyjne,

- bezpieczeństwo architektoniczne,

- bezpieczeństwo środowiskowo-technologiczne,

- bezpieczeństwo imprez masowych i zgromadzeń,

- bezpieczeństwo obyczajowe.

Bezpieczeństwo publiczne obejmuje zatem ogół przedsięwzięć podejmowanych przez administrację publiczną w formie polityki regulacyjnej i działań planistyczno-organizacyjnych w celu zapewnienia społeczeństwu odpowiedniego poziomu bezpieczeństwa i szybkiej pomocy w przypadku wystąienia określonego zagrożenia. Odnosi się również do środowiska, w jakim funkcjonuje dana społeczność i zależy od infrastruktury fizycznej (np. sieci dróg, terenów zielonych, systemów alarmowych), które tworzą warunki do prowadzenia działań [25], [26].

Cechą wyróżniającą systemu bezpieczeństwa publicznego jest to, że nawet ten sam typ zagrożenia w każdym przypadku ma inny charakter, przebieg, intensywność i lokalizację oraz wymaga specyficznego dla danej sytuacji podejścia. Przykładowo przebieg pożaru budynku mieszkalnego będzie zależał m.in. od takich czynników jak: rodzaj zabudowy, typ wykończenia wewnetrznego (np. drewno), rodzaj przechowywanych materiałów (np. butle gazowe w piwnicy), pora roku. Podobnie działania interwencyjno-ratownicze w tym 
przypadku będą zależały od powyższych czynników, a także od liczby osób zagrożonych i innych warunków sytuacyjnych. Z tego względu bezpieczeństwo publiczne wymaga odpowiedniego zarządzania o niskim stopniu jego ustrukturyzowania, gdyż sama realizacja procedur może być niewystarczająca.

\section{Zarządzanie bezpieczeństwem publicznym. Model systemu}

Zarządzanie bezpieczeństwem publicznym jest zorganizowanym działaniem realizowanym przy wykorzystaniu zasobów kadrowych, finansowych, technicznych oraz informacyjnych wielu organizacji, a niejednokrotnie także spontanicznie uaktywniających się grup społecznych. Jest ono podejmowane w celu zmniejszania potencjalnych zagrożeń, zapewnienia niezakłóconego przebiegu życia społecznego, a także ochrony zdrowia i życia ludzi oraz mienia i środowiska [27, s. 124]. Głównym celem zarządzania bezpieczeństwem publicznym jest uniemożliwienie przekroczenia dopuszczalnego poziomu ryzyka wystąpienia zagrożeń i utraty kontroli nad nimi [28, s. 1263], [29, s. 499]. Stanowi ono proces ciągły i dynamiczny, ukierunkowany na zapobieganie i zwalczanie zagrożeń, które mogą mieć swoje źródło w [30]: zachowaniach ludzi (zagrożenia społeczne), rozwoju technologicznym (zagrożenia techniczne) i zagrożeniach naturalnych (zagrożenia środowiskowe). Proces zarządzania bezpieczeństwem publicznym ma na celu zapewnienie optymalnego poziomu bezpieczeństwa przy istniejących możliwościach i ograniczeniach oraz przy uwzględnieniu dynamiki otoczenia. Rozpoczyna się od identyfikacji potencjalnych zagrożeń i oceny ryzyka ich wystąpienia. Na tej podstawie prowadzone są analizy potrzeb w zakresie organizacji działań i przygotowywane są plany operacyjne. Działania te stanowią elementy procesu planowania. W czasie organizowania prowadzony jest bilans sił i środków, pozyskiwane są dodatkowe zasoby, następuje podział zadań i odpowiedzialności i przygotowanie zasobów. Z kolei proces realizowania obejmuje prowadzenie działań interwencyjnych, ratowniczych, zabezpieczających i pomocowych, a w tym komunikowanie się i koordynowanie działań. Ostatnim etapem jest kontrola obejmująca sprawdzenie poprawności realizowanych działań i identyfikację potencjalnych usprawnień. Stanowi ona podstawę doskonalenia działań w ramach adaptacyjnego uczenia się.

Odpowiedzialność za zarządzanie bezpieczeństwem publicznym spoczywa na państwie i właściwych organach władzy państwowej, a podstawowymi podmiotami w tym zakresie są gminy, powiaty i województwa [31-36]. Poziom centralny odpowiada za zarządzanie strategiczne i ciągłość funkcjonowania całej administracji, spełnia rolę ustawodawczą, monitoruje i koordynuje przebieg przedsięwzięć, a w razie potrzeby przejmuje dowodzenie nad realizowanymi działaniami. Natomiast samorządy mają bezpośrednią możliwość oddziaływania na poziom bezpieczeństwa publicznego poprzez podejmowanie odpowiednich inicjatyw. Przykładowo mogą wdrażać programy prewencyjne, utrzymywać magazyny przeciwpowodziowe, wspierać formacje działające na rzecz bezpieczeństwa poprzez dofinansowywanie działań, wpływać kształtować bezpieczne przestrzenie publiczne czy też ukierunkowywać polityki społeczne na przeciwdziałanie bezrobociu, promocję i ochronę zdrowia, pomoc społeczną, politykę prorodzinną, edukację i kulturę. Analiza ustawowych zadań samorządów wskazuje, że wpływają one - nie tylko bezpośrednio - na poziom bezpieczeństwa publicznego. Poprzez realizację swoich pozostałych zadań kształtują one warunki życia w regionie, przez co pośrednio oddziałują na bezpieczeństwo. Warto również zaznaczyć, że podstawowym poziomem zarządzania bezpieczeństwem publicznym jest powiat (miasto na prawach powiatu) wraz z gminami, gdyż „znaczną część przedsięwzięć w dzisiejszym świecie można podjąć jedynie przy skali 50-150 tysięcy mieszkańców. Dopiero taka skala wytwarza warunki demograficzne, organizacyjne, intelektualne, instytucjonalne, także gospodarcze do zarządzania" [37, s. 354]. Poziom wojewódzki z kolei ma możliwość wspierania i koordynowania działalności powiatów.

Rola samorządów w zakresie zarządzania bezpieczeństwem publicznym w głównej mierze polega na planowaniu i przygotowywaniu działań w taki sposób, aby zapewnić ich sprawny przebieg. Na barkach samorządów spoczywa inicjowanie przedsięwzięć, zabezpieczenie środków finansowych na realizację zadań, a także monitoring przebiegu tych działań oraz kontrola ich efektów. W ten sposób oraz poprzez zwierzchnictwo nad służbami, inspekcjami i strażami na danym obszarze administracyjnym samorządy wpływają na przebieg działań w przypadku wystąpienia zagrożeń. Jednakże sama realizacja zaplanowanych przedsięwzięć leży w kompetencjach właściwych służb, inspekcji i straży. Jednostki te są odpowiednio przygotowane operacyjnie, posiadają właściwe umiejętności i wiedzę oraz dysponują środkami i narzędziami adekwatnymi do sytuacji. Realizują działania na podstawie obowiązujących regulacji prawnych i rozwiązań systemowych, jak na przykład Krajowy System Ratowniczo-Gaśniczy, System 112 i System Państwowe Ratownictwo Medyczne. Przeprowadzone badania własne pozwoliły 
zidentyfikować grupy jednostek tworzących w Polsce SZBP ze względu na realizowane przez nie funkcje. Należą do nich:

1. Samorząd terytorialny, który bezpośrednio i pośrednio wpływa na poziom bezpieczeństwa publicznego.

2. Jednostki interwencyjno-ratownicze, a w tym:

- jednostka główna, w której kompetencjach leży podejmowanie działań w przypadku wystąpienia określonego rodzaju zagrożenia; spełnia ona wiodącą rolę w przypadku określonego zdarzenia;

- jednostki pomocnicze, które pomagają w realizacji działań jednostce głównej;

- jednostki uzupełniające, których wiedza i kompetencje są pomocne w określonej sytuacji; są to m.in. inspekcja farmaceutyczna, inspekcja sanitarno-epidemiologiczna, inspekcja weterynaryjna, inspekcja ochrony roślin, inspekcja transportu drogowego, inspekcja nadzoru budowlanego, inspekcja ochrony środowiska, inspekcja handlowa, państwowa agencja atomistyki, lasy państwowe, generalna dyrekcja dróg krajowych i autostrad, pogotowie gazowe, pogotowie energetyczne, służby ochrony lotnisk i inne niezbędne w określonej sytuacji.

3. Społeczeństwo: społeczności lokalne i przedsiębiorstwa funkcjonujące na danym obszarze terytorialnym.

4. Media: radio, telewizja, prasa, internet.

5. Organizacje pozarządowe, które obejmują ratownictwo ochotnicze (np. ochotnicze straże pożarne, wodne ochotnicze pogotowie ratunkowe, górskie ochotnicze pogotowie ratunkowe), organizacje zajmujące się pomocą humanitarną (np. Polski Czerwony Krzyż), a także stowarzyszenia i fundacje ukierunkowane na zwalczanie problemów społecznych (np. przemocy, alkoholizmu) oraz ratownictwo komercyjne (np. pomoc drogowa).

6. Jednostki badawczo-rozwojowe funkcjonujące przy jednostkach interwencyjno-ratowniczych (np. laboratoria), szkoły wyższe prowdzące badania w zakresie bezpieczeństwa wewnętrznego, a także instytuty badawcze.

Wymienione grupy podmiotów stanowią złożony i dynamiczny system, a ich rola zmienia się w zależności od sytuacji i rodzaju zagrożenia [38, s. 96]. Model tego systemu przy uwzględnieniu uwarunkowań realizacji działań zilustrowano na rycinie 1.

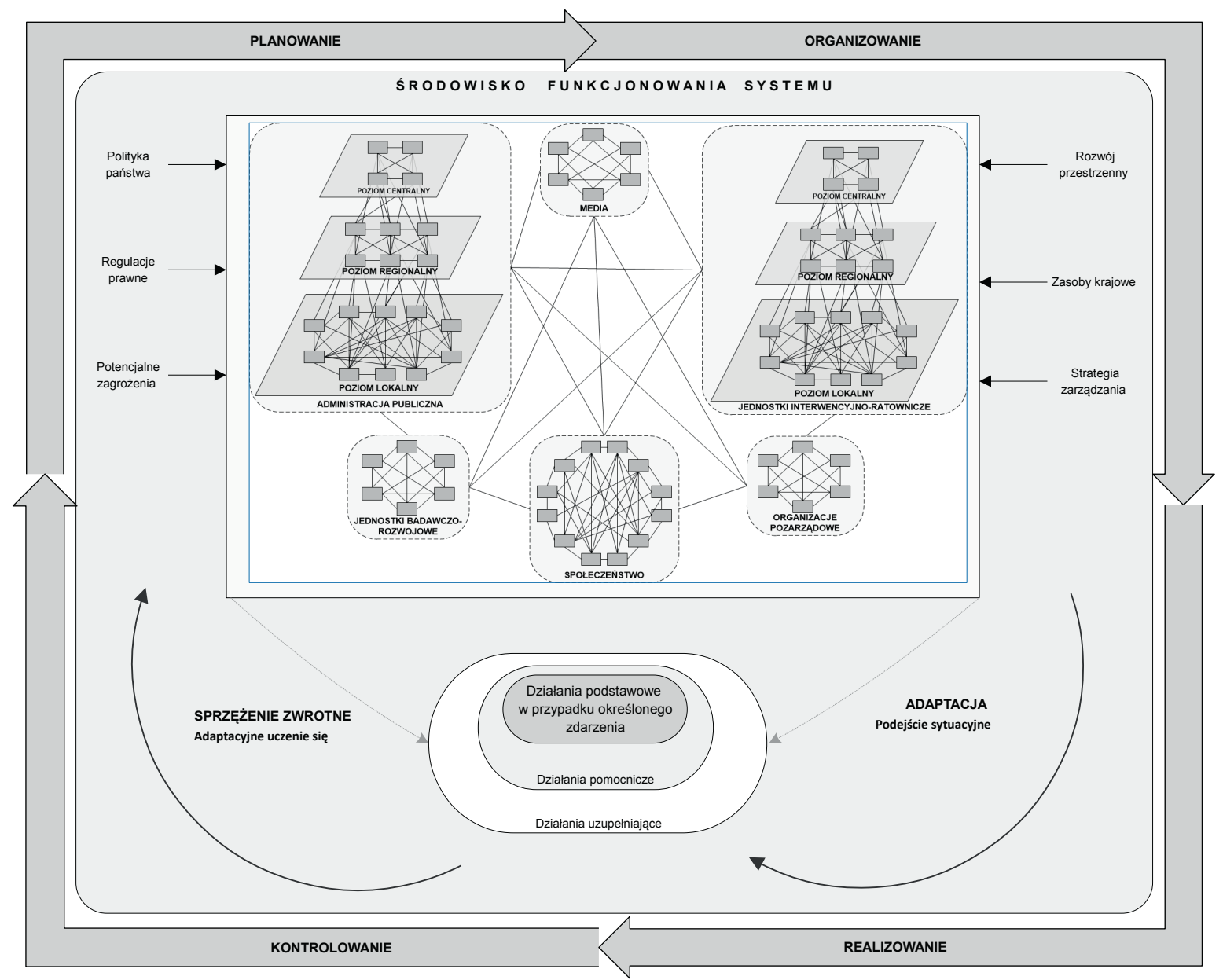




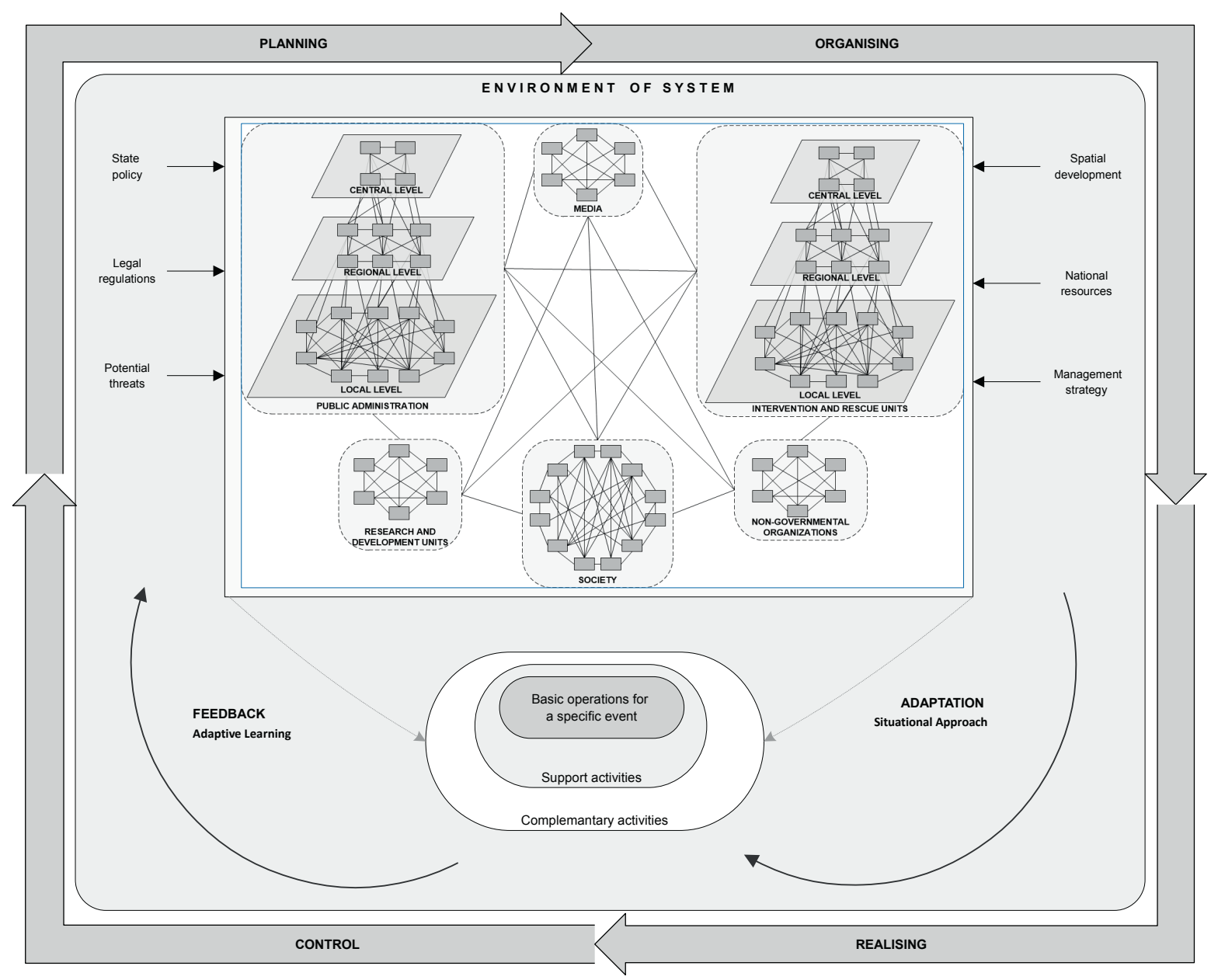

Ryc. 1. Model systemu zarządzania bezpieczeństwem publicznym

Fig. 1. Model of public safety management system

Źródło: Opracowanie własne. Source: Own elaboration.

SZBP stanowi złożony układ podmiotów zaangażownych w realizację działań w określonych uwarunkowaniach, w każdym przypadku odmiennie, w zależności od sytuacji i stanu zagrożenia. W okresie stabilizacji (planowanie i organizowanie działań) samorząd terytorialny odgrywa wiodącą rolę w SZBP na danym terenie administracyjnym. W tym okresie priorytet stanowi zapobieganie zagrożeniom, osiągane poprzez edukację, wychowanie i przygotowanie do przeciwstawienia się trudnym sytuacjom. Funcje te realizowane są przede wszystkim przez oświatę, media, organizacje pozarządowe i samorządy w ramach kształtowania kultury i tożsamości narodowej. Również Policja i Państwowa Straż Pożarna przygotowują programy prewencyjne mające na celu niedopuszczenie do wystąpienia zagrożeń.

Z kolei w okresie realizacji (interweniowanie, zwalczanie zagrożeń) wiodącą rolę przejmują jednostki interwencyjno-ratownicze, a samorządy koordynują prowadzone działania. Przeprowadzone badania pozwoliły również stwierdzić, że podstawową funkcję w realizacji działań interwencyjnych i ratowniczych spełniają: policja, straż pożarna (państwowa i ochotnicza) i ratownicy medyczni. Jednostki te najczęściej w pierwszej kolejności biorą udział w działaniach. W zależności od rodzaju zagrożenia i sytuacji angażowane są również inne podmioty. Podstawowe działania może wspomagać m.in. straż gminna, straż graniczna, straż ochrony kolei, Inspekcja Transportu Drogowego, wojsko, czy też organizacje pozarządowe (np. OSP, WOPR, GOPR itp.). Z kolei Inspekcja Ochrony Środowiska, Inspekcja Sanitarna, Inspekcja Nadzoru Budowlanego czy też pracownicy pomocy społecznej mogą pełnić rolę doradczą i wspomagać podejmowanie decyzji, służąc wiedzą specjalistyczną (działania uzupełniające). Zaangażowanie poszczególnych jednostek zależy od poziomu złożoności danej sytuacji.

Na skuteczność funkcjonowania SZBP wpływa zatem rodzaj zagrożenia, uwarunkowania sytuacyjne, środowisko wewnętrzne (np. regulaminy poszczególnych jednostek) i zewnętrzne (np. polityka i strategia zarządzania państwem, obowiązujące regulacje 
prawne, potencjalne zagrożenia). Wyniki przeprowadzonych badań wskazują, że niemniej istotne znaczenie posiadają zachowania organizacyjne, a w tym zaufanie i zaangażowanie. Jakość podejmowanych działań zależy bowiem od chęci i dobrej woli poszczególnych jednostek i osób, a także zrozumienia roli spełnianej w danej sytuacji. Z tego względu zarówno uwarunkowania formalne, jak i nieformalne odgrywają istotną rolę w SZBP. Na kanwie charakterystyk CAS i przeprowadzonych badań można stwierdzić, że SZBP posiada wszystkie cechy CAS, a mianowicie:

1. Dużą liczbę elementów. Działania realizowane są przez organizacje z różnych sektorów, które same stanowią złożone systemy. Organizacje odgrywające podstawową rolę w bezpieczeństwie publicznym (administracja publiczna, jednostki interwencyjno-ratownicze) funkcjonują na wszystkich poziomach organizacji państwa. Ich działania wspierają pozostałe podmioty systemu, a w tym organizacje pozarządowe, uniwersytety, media, sektor prywatny.

2. Zmienność. Do działań kierowanych jest wiele zasobów, w różnej ilości i konfiguracji. W każdym przypadku odmiennie, w zależności od potrzeb.

3. Samoorganizację. Elementy systemu podlegają nieustającemu, spontanicznemu porządkowaniu. Struktury tworzą się pod wpływem relacji zachodzących pomiędzy elementami systemu oraz pomiędzy tym systemem a jego otoczeniem.

4. Różnorodność. System ukierunkowany jest na zapobieganie i zwalczanie zagrożeń społecznych, naturalnych i technicznych. Skala i rodzaj zagrożeń stanowią podstawę różnorodności podejmowanych działań.

5. Dynamizm i żywotność. Każde zdarzenie, nawet tego samego rodzaju, jest odmienne - przebiega $\mathrm{w}$ innym czasie, $\mathrm{w}$ innym miejscu, obwarowane jest innymi warunkami, charakteryzuje się inną dynamiką i zmiennością rozwoju, zagrożone sa inne osoby, odmienny jest przebieg zdarzeń, a zasoby angażowane sa w innych proporcjach itd.

6. Zdolności adaptacyjne. Uwarunkowania realizacji działań stwarzają potrzebę indywidualnego podejścia do każdego zagrożenia, adekwatnie do pojawiających się potrzeb i wymagań danej sytuacji. Elementy systemu łączą czynniki niezależne od siebie, które stwarzają warunki do ciągłej i spontanicznej adaptacji do zmian otoczenia.

7. Interakcje. Jednostki SZBP prowadzą działania w ramach współpracy międzyorganizacyjnej budowanej na podstawie formalnych i nieformalnych relacji.
8. Brak liniowości. Nigdy nie jest wiadome, jaki będzie wynik działań, a zaangażowane śródki nie są wprost proporcjonalne do osiąganych rezultatów.

9. Selekcję. W każdym przypadku istnieje wiele możliwości i strategii przeprowadzenia działań. Wybór najlepszego rozwiązania leży w kompetencjach jednostki wiodącej w danej sytuacji, np. komendanta straży pożarnej w czasie zagrożenia pożarowego, komendanta policji w przypadku zamieszek i demonstracji.

Zastosowanie teorii złożoności w SZBP uzasadnione jest koniecznością kompleksowego i adaptacyjnego podejścia do każdej sytuacji indywidualnie, a także potrzeby uczenia się i doskonalenia działań. Złożoność SZBP wynika z jego zróżnicowania, o czym świadczy podkreślona już liczba i różnorodność zaangażowanych jednostek, $\mathrm{z}$ interakcji zachodzących pomiędzy jego elementami, współzależności tworzonej przez powiązanie ze sobą poszczególne zadań, adaptacji do środowiska będącej podstawą uczenia się oraz z powstających $\mathrm{w}$ trakcie jego funkcjonowania nowych, specyficznych cech. Powyższe rozważania pozwalają stwierdzić, że SZBP stanowi dynamiczny układ nieskończonej liczby jednostek, którego celem jest zapewnienie bezpiecznych warunków funkcjonowania wszystkim podmiotom na danym obszarze administracyjnym przy wykorzystaniu posiadanych zasobów i w ramach obowiązujących reguł formalnych i nieformalnych relacji, charakteryzujący się niepowtarzalnością i zmiennością działań oraz ciągłym dostosowywaniem się do aktualnych warunków i pojawiających się potrzeb.

\section{Dyskusja nad metodami i wynikami}

Przeprowadzona analiza desk research zarówno literatury polskiej, jak i zagranicznej wykazała trudności w sprecyzowaniu obszaru badawczego bezpieczeństwa publicznego. Wynikało to w głównej mierze ze wskazywanych w literaturze rodzajów bezpieczeństwa, np. bezpieczeństwo państwa, bezpieczeństwo wewnętrzne, bezpieczeństwo społeczne, bezpieczeństwo powszechne, bezpieczeństwo ekonomiczne, bezpieczeństwo polityczne itd., a także miejsca bezpieczeństwa publicznego w ogólnej teorii bezpieczeństwa. Pogłębiona analiza wykazała, że przyjęta terminologia zależy od perspektywy prowadzonych badań. Po wzięciu pod uwagę, że bezpieczeństwo publiczne stanowi kategorię zarządzania publicznego, określono jego obszar badawczy, który obejmuje sposoby właściwej realizacji działań 
przez podmioty tworzące SZBP na danym terenie administracyjnym.

Z kolei analiza aktów prawnych i dokumentów wewnętrznych w kontekście wyników przeprowadzonych wywiadów wyeksponowała złożoność problematyki zarządzania bezpieczeństwem publicznym. Złożoność ta wynika z dużej liczby jednostek biorących udział w działaniach i charakteru relacji zachodzących między nimi, a także zmienności, różnorodności i dynamiki zdarzeń. $Z$ tego względu do zrozumienia przebiegu procesów w zarządzaniu bezpieczeństwem publicznym uzasadnione okazało się zastosowanie teorii złożoności. Podejście takie umożliwiło identyfikację uwarunkowań w kształtowaniu struktury i zachowań w ramach SZBP. W rezultacie opracowano model SZBP, który umożliwia kompleksowe ujęcie problematyki zarządzania bezpieczeństwem publicznym. Trudno bowiem dopatrywać się źródeł skuteczności działań jedynie w regulacjach prawnych czy rozwiązaniach organizacyjnych. Poszczególne uwarunkowania są współzależne i jedynie kompleksowe uwzględnienie warunków (organizacyjno-prawnych, środowiskowych i sytuacyjnych), angażowanych podmiotów i relacji zachodzących między nimi, a także realizowanych procesów umożliwia zrozumienie złożonego charakteru SZBP.

\section{Podsumowanie}

Zarządzanie bezpieczeństwem publicznym jest jednym z podstawowych zadań państwa, a realizowane jest przede wszystkim przez instytucję samorządu

\section{Literatura}

[1] Pieprzny S., Źródła zagrożeń bezpieczeństwa i porzadku publicznego (wybrane zagadnienia administracyjno-prawne), „Zeszyty Naukowe Politechniki Rzeszowskiej, Zarządzanie i Marketing" z. 11, 245, 2007, 87-100.

[2] Mesjasz C., Metody zarządzania złożonymi zagrożeniami geopolitycznymi we współczesnym świecie, w: Zarządzanie bezpieczeństwem, metody i techniki, K. Raczkowski, K. Sułkowski (red.), Difin, Warszawa 2014, 121-164.

[3] Gell-Mann M., Kwark i Jaguar - przygodyz prostotą i złożonościa, Wydawnictwo CIS, Warszawa 1996.

[4] Nowak W.A., Rachunkowość sektora publicznego. Koncepcje, metody, uwarunkowania, Wydawnictwo Naukowe PWN, Warszawa 1998.

[5] Pascale R.T., Surfing the edge of chaos, Sloan Management Review, 1999, 83-94. terytorialnego. Działania w tym zakresie ukierunkowane są na zwalczanie zagrożeń o charakterze społecznym, technicznym i naturalnym. Dotyczą one zarówno bezpośrednich, jak i pośrednich działań będących rezultatem i wpływem realizowanych polityk publicznych.

Bezpieczeństwo publiczne kształtowane jest w wyniku przedsięwzięć podejmowanych przez wiele jednostek, które tworzą SZBP. Zależy od uwarunkowań organizacyjno-prawnych, sytuacyjnych, a także środowiska funkcjonowania tego systemu. W SZBP kompetencje poszczególnych jednostek uzupełniają i wzmacniają się, a codzienna praktyka służy pogłębianiu formalnych i nieformalnych relacji, a także kształtuje zachowania organizacyjne poszczególnych jednostek i ludzi. Ponadto poprzez doświadczanie i adaptacyjne uczenie się SZBP ewoluuje. Punktem wyjściowym jego skuteczności jest zrozumienie zależności pomiędzy uwarunkowaniami w realizacji podejmowanych działań. $W$ tym zakresie pomocny może okazać się opracowany przy wykorzystaniu cech CAS model SZBP, który uwzględnia podmioty, procesy i uwarunkowania realizacji działań w badanym systemie.

Badania przedstawione $\mathrm{w}$ artykule przeprowadzono w ramach projektu badawczego „Koordynacja, komunikowanie i zaufanie jako czynniki skutecznej współpracy międzyorganizacyjnej w systemie zarządzania bezpieczeństwem publicznym" sfinansowanego ze środków Narodowego Centrum Nauki przyznanych na podstawie decyzji numer DEC-2012/07/D/ HS4/00537.

[6] Tetenbaum T., Shifting paradigms: from Newton to chaos, "Organizational Dynamics", Vol. 26 Issue 4, 1998, pp. 21-32.

[7] Keene A., Complexity theory: the changing role of leadership, "Industrial and Commercial Training", Vol. 32 Issue 1, 2000, pp. 15-18.

[8] Smith A.C.T., Graetz F., Complexity theory and organizing form dualities, "Management Decision”, Vol. 44 Issue 7, 2006, pp. 851-870.

[9] Levy, David L., Applications and Limitations of Complexity Theory in Organization Theory and Strategy, w: Handbook of Strategic Management, Second Edition, J. Rabin, G.J. Miller, W.B. Hildreth (red.), Marcel Dekker, New York 2000, 67-87.

[10] Blomme R.J., Bornebroek-Te Lintelo K., Existentialism and organizational behaviour: How existentialism can contribute to complexity theory and sense-making, "Journal of Organizational 
Change Management”, Vol. 25 Issue 3, 2012, pp. 405-421.

[11] Espinosa A., Porter T., Sustainability, complexity and learning: insights from complex systems approaches, "Learning Organization", Vol. 18 Issue 1, 2011, pp. 54-72.

[12] Wulun J., Understanding complexity, challenging traditional ways of thinking, "Systems Research and Behavioral Science", Vol. 24 Issue 4, 2007, pp. 393-402.

[13] Kożuch B., Zarzadzanie publiczne w zarysie, Wydawnictwo Fundacja Współczesne Zarządzanie, Białystok 2003.

[14] Tilebein M., A complex adaptive systems approach to efficiency and innovation, "Kybernetes", Vol. 35 Issue 7-8, 2006, pp. 1087-1099.

[15] Palmberg K., Complex adaptive systems as metaphors for organizational management, "Learning Organization”, Vol. 16 Issue 6, 2009, pp. 483-498.

[16] Benbya H., McKelvey B., Toward a complexity theory of information systems development, "Information Technology \& People", Vol. 19 Issue 1, 2006, pp. 12-34.

[17] Choenni S., Leertouwer E., Public Safety Mashups to Support Policy Makers, w: Electronic Government and the Information Systems Perspective, K.M. Andersen, E. Francesconi, A.G.T.M. van Engers (red.), First International Conference, EGOVIS, 2010, Bilbao, Spain, August 31-September 2, Springer-Verlag Berlin Heidelberg, 2010, 234-248.

[18] Lisiecki M., Kwiatkowska-Basałaj B., Pojęcie bezpieczeństwa oraz prognostyczny model jego zapewnienia, w: Zarządzanie bezpieczeństwem: międzynarodowa konferencja naukowa, $\mathrm{P}$. Tyrała (red.), Wydawnictwo Profesjonalnej Szkoły Biznesu, Kraków 2000, 57-58.

[19] Smith M.E., What Future for "Public Safety" and "Restorative Justice" in Community Corrections?, National Institute of Justice, 2001 [dok. elektr.] https://www.ncjrs.gov/txtfiles1/nij/187773.txt [dostęp 7 lipca 2014].

[20] Kożuch B., Sienkiewicz-Małyjurek K., New Requirements for Managers of Public Safety System, "Procedia - Social and Behavioral Sciences", Vol. 149, 2014, pp. 472-478.

[21] Gromek P., Wróbel R., Gikiewicz M., Analiza systemu bezpieczeństwa publicznego i jego relacji $z$ innymi podmiotami bezpieczeństwa państwa w odniesieniu do Państwowej Straży Pożarnej, „Zeszyty Naukowe SGSP”, Vol. 46 Issue 2, 2013, pp. 65-93.
[22] Zaborowski J., Administracyjnoprawne ujęcie pojęć bezpieczeństwo publiczne i porzadek publiczny, „Zeszyty Naukowe ASW”, Vol. 41, 1985, pp. 129-130.

[23] Comfort L.K., Rethinking Security: Organizational Fragility in Extreme Events, "Public Administration Review”, Vol. 62, 2002, pp. 98-107.

[24] Fehler W., Bezpieczeństwo publiczne, „Społeczeństwo i Polityka", Vol. 21 Issue 4, 2009, pp. 30-39.

[25] Fleischner J., von Hippel K., Barton F., Homebound Security, Migrant Support for Improved Public Safety in Conflict-Prone Settings, A Report of the CSIS Post-Conflict Reconstruction Project, Center for Strategic and International Studies, Washington, 2009.

[26] Mroczko F., Problemy bezpieczeństwa i porzadku publicznego, „Zeszyty Naukowe Wałbrzyskiej Wyższej Szkoły Zarządzania i Przedsiębiorczości", 14/1, 2010, 33-41.

[27] Sienkiewicz-Małyjurek K., Rola samorządów lokalnych $w$ kształtowaniu bezpieczeństwa publicznego, „Samorząd Terytorialny”, Issue 7-8, 2010, pp. 123-139.

[28] Reiman T., Rollenhagen C., Human and organizational biases affecting the management of safety, "Reliability Engineering \& System Safety", Vol. 96 Issue 10, 2011, pp. 1263-1274.

[29] Vinodkumar M.N., Bhasi M, A study on the impact of management system certification on safety management, "Safety Science", Vol. 49 Issue 3, 2011, pp. 498-507.

[30] Sienkiewicz-Małyjurek K., Niczyporuk Z., Bezpieczeństwo publiczne. Zarys problematyki, Wydawnictwo Politechniki Śląskiej, Gliwice 2010.

[31] Konstytucja Rzeczypospolitej Polskiej z dnia 2 kwietnia 1997 r. (Dz.U. 1997 nr 78 poz. 483).

[32] Ustawa z dnia 23 stycznia 2009 r. o wojewodzie i administracji rządowej w województwie (Dz.U. $2009 \mathrm{nr} 31$ poz. 206).

[33] Ustawa z dnia 5 czerwca 1998 r. o samorządzie powiatowym (Dz. U. $2001 \mathrm{nr} 142$ poz. 1592, ze zm.).

[34] Ustawa z dnia 5 czerwca 1998 r. o samorządzie województwa (Dz. U. $2001 \mathrm{nr} 142$ poz. 1590, ze zm.).

[35] Ustawa z dnia 8 marca 1990 r. o samorządzie gminnym (Dz. U. $2001 \mathrm{nr} 142$ poz. 1591, ze zm.).

[36] Ustawa $z$ dnia 26 kwietnia 2007 r. o zarządzaniu kryzysowym (Dz.U. $2007 \mathrm{nr} 89$ poz. 590, ze zm.).

[37] Kulesza M., Budowanie samorządu, Municipium, Warszawa, 2008.

[38] Niczyporuk Z.T., Sienkiewicz-Małyjurek K., Systemy monitoringu wizyjnego w bezpieczeństwie publicznym, Wydawnictwo Politechniki Śląskiej, Gliwice 2008. 
dr Katarzyna Sienkiewicz-Małyjurek - doktor nauk ekonomicznych, pracownik Instytutu Zarządzania i Administracji na Wydziale Organizacji i Zarządzania Politechniki Śląskiej. Zainteresowania naukowe skupia wokół zagadnień doskonalenia działań i współpracy międzyorganizacyjnej w zarządzaniu bezpieczeństwem publicznym i w zarządzaniu kryzysowym.

prof. dr hab. Barbara Kożuch - profesor nauk ekonomicznych, pracownik Instytutu Spraw Publicznych na Wydziale Zarządzania i Komunikacji Społecznej Uniwersytetu Jagiellońskiego. Specjalizuje się w teorii organizacji, systemach i metodach zarządzania, zarządzaniu publicznym oraz zarządzaniu zasobami ludzkimi. W szczególności bada podstawy teoretyczne nauk o zarządzaniu, warunki sprawnego funkcjonowania sektora publicznego, zasady zarządzania publicznego w administracji publicznej i organizacjach obywatelskich, a także współdziałanie organizacyjne i zarządzanie zmianami w systemie ochrony zdrowia, oświaty i kultury, a także ładu i porządku publicznego. 